\title{
PĀRROBEŽU PATĒRĒTĀJU STRĪDI: EIROPAS TIESU IZVĒLES IESPĒJAS POTENCIĀLĀS TIESVEDĪBAS NOLŪKOS
}

\section{CROSS-BORDER CONSUMER DISPUTES: POSSIBLE CHOICES FOR EUROPEAN COURTS OF POTENTIAL LITIGATION PURPOSES}

\author{
Irēna Kucina, Dr. iur. \\ Latvijas Universitātes Juridiskās fakultātes \\ Starptautisko un Eiropas tiesību zinātṇu katedras asociētā profesore
}

\section{Summary}

One of the objectives of the European Union is creation of an internal market for consumer goods, an area in which free goods and services are provided, including crossborder transactions with consumers. These transactions increasingly take place via the Internet. Online shopping makes it easier for consumers to compare prices, thus saving money, which, in turn, has a positive impact on competition.

In cross-border transactions, the consumer is undoubtedly the weaker party, especially when it comes to e-commerce, because in most cases this person has to pay before delivery. As a result, if there is any problem with the performance of the contract, the first will have to act for the consumer rather than the seller or service provider.

If such a cross-border dispute is not resolved in a simple and inexpensive way, consumers may be hesitant to engage in cross-border and e-commerce transactions, thus jeopardizing the functioning of the EU internal market.

The consumer mostly thinks of a traditional court solution in case of a dispute. Therefore, in such cases, the consumer will always have to find answers to two important questions:

(a) in which court to bring an action in the EU territory; and

b) if a judgment is passed in favour of the consumer, what obstacles must be overcome in order to comply with the judgment?

Atslēgvārdi: starptautiskais civilprocess, pārrobežu lietu piekritība, pārrobežu patērētāju strīdi, Briseles Ibis regula

Keywords: international civil procedure, cross-border jurisdiction, cross-border consumer disputes, Brussels Ibis Regulation

\section{Ievads}

Neskatoties uz Eiropas Savienības (turpmāk - ES) likumdevēja gribu pārrobežu patērētāju strīdiem izveidot skaidru starptautisko civilprocesu un Eiropas Savienības Tiesas (turpmāk - EST) judikatūrā nostiprinātu plašu atziṇu klāstu 
šajā jautājumā, strīdus gadījumā patērētājs pārsvarā domā par tradicionālu, vienkāršu un lētu tiesas risinājumu. Patērētājam ir būtiski sameklēt atbildes uz diviem jautājumiem:

1) kuras valsts tiesā ES teritorijā celt prasību,

2) ja tiek pieṇemts spriedums par labu patērētājam, kādi šḳēršli ir jāpārvar, lai šo spriedumu izpildìtu?

Vai tas ir vienkārši iespējams, autore koncentrētā veidā mēgeinās atbildēt rakstā.

\section{Būtiskākais pārrobežu patērētāju strīdos saskaṇā Briseles Ibis regulu}

Pārrobežu strīdos pie noteiktiem kritērijiem patērētājs var tikt uzskatīts par vājāko pusi un ES likumdevējs ir paredzējis patēētājam īpašu jeb labvēlīgāku jurisdikcijas noteikumu režìmu.

Atbilstoši Briseles regulējuma starptautisko privāttiesību instrumentiem ${ }^{1}$ īpašo jurisdikcijas pamatu režìmu veido trīs galvenie elementi:

1) vājākajai pusei ir pieejami papildu un labvēlīgi jurisdikcijas pamati, ja viṇa darbojas kā prasītājs;

2) ierobežojums, kas noteic, ka vājākā puse, ja tā ir atbildētājs lietā, var tikt iesūdzēta tikai tā domicila dalībvalstī;

3) ir būtiski ierobežota pušu iespēja vienoties par tiesu, lai atkāptos no iepriekš minētā ìpašā jurisdikcijas režìma.

Jāatzīmē arī tas, ka pārrobežu patērētāju strīdos Briseles regulējuma starptautisko privāttiesību instrumentu piemērošanas sistēma ir labi zināma un laika gaitā pārbaudīta un apstiprināta EST judikatūrā - piemēram, lietā C-269/95 Benincasa un lietā C-464/01 Gruber par Briseles konvencijā ietverto patērētāju strīdu piekritības noteikumu attiecināšanu uz gadījumiem, kad preces iegādātas vai pakalpojumi saņemti personas gan kā patērētāja, gan kā uzṇēmēja vajadzībām, ${ }^{2}$ apvienotajās lietās C-585/08 un C144/09 Pammer un Hotel Alpenhof par piekritību gadījumā, ja tūrisma pakalpojumi pasūtīti internetā, ${ }^{3}$ lietā C-190/11 Mühlleitner par Briseles I regulas attiecināmību uz līgumiem, kuru izpilde notiek klātienē, bet rezervācija veikta attālināti, ${ }^{4}$ lietā C33/78 Somafer SA/Saar-Ferngas $A G$ par strīda piekritību gadījumā, ja līgums noslēgts ar filiāli, aǵentūru vai citu nodibinājumu, ${ }^{5}$ kā arī jaunākajā EST judikatūrā, piemēram, lietā C-630/17 Milivojević par Briseles I bis regulas nepiemērojamību gadījumā, ja persona saṇēmusi kredīu remontdarbu veikšanai, kas nepieciešami tūristu izmitināšanas pakalpojumu sniegšanai, ${ }^{6}$ un daudzās citās lietās.

1 Briseles konvencija par piekritību un spriedumu atzišanu un izpildi civillietās un komerclietās. Pieejams: http://eur-lex.europa.eu/legal-content/EN/TXT/?uri=CELEX:41968A0927(01) [aplūkots 15.03.2019.]; Padomes 22.12.2000. Regula Nr. 44/2001 (EK) par jurisdikciju un spriedumu atzī̌anu un izpildi civillietās un komerclietās. Publicēta OV 2004. gada îpašā izdevuma 19. nodaḷas 4. sējuma 42.-64. lpp.; Eiropas Parlamenta un Padomes Regula Nr. 1215/2012 (2012. gada 12. decembris) par jurisdikciju un spriedumu atzīšanu un izpildi civillietās un komerclietās. Publicēta OV 20.12.2012., L 351, 1./32. lpp. (BG, ES, CS, DA, DE, ET, EL, EN, FR, GA, IT, LV, LT, HU, MT, NL, PL, PT, RO, SK, SL, FI, SV) İpašais izdevums horvātu valodā: 19. nodaḷa, 011. sējums, 289.-320. lpp.

2 Eiropas Kopienu tiesas 03.07.1997. spriedums lietā C0269/95 Benincasa/Dentalkit; Eiropas Kopienu tiesas 20.01.2005. spriedums lietā C-464/01 Gruber.

3 Eiropas Savienības Tiesas 07.12.2010. spriedums lietā C-585/08 Pammer un Hotel Alpenhof.

4 Eiropas Savienības Tiesas 06.09.2012. spriedums lietā C-190/11 Mühlleitner.

Eiropas Kopienu tiesas 22.11.1978. spriedums lietā C-33/78 Somafer SA/Saar-Ferngas AG.

6 Eiropas Savienības Tiesas 14.02.2019. spriedums lietā C-630/17 Milivojević. 
Briseles I regulas pārstrādātajā redakcijā jeb Eiropas Parlamenta un Padomes Regulā Nr. 1215/2012 (2012. gada 12. decembris) par jurisdikciju un spriedumu atzī̌sanu un izpildi civillietās un komerclietās, ${ }^{7}$ kas piemērojama visās dalībvalstīs (ieskaitot Dāniju ${ }^{8}$ ), ir paredzēti jurisdikcijas noteikumi, kas patērētājam ir izdevīgi (18.-19. pants), bet ar vienu būtisku nosacìjumu, ka līgums ietilpst šīs regulas 17. panta ierobežojošajā darbības jomā. Ja nē, tad ir piemērojami vispārējie jurisdikcijas noteikumi saskaṇā ar minētās regulas 4. pantu vai arī 7.-9. pantu.

Pēc būtības līdzīga piemērošanas shēma bija paredzēta arī Briseles I regulā, ${ }^{9}$ paredzot patērētājam labvēlīgāku jurisdikcijas noteikumu režìmu, nekā noteikts profesionālam pakalpojuma sniedzējam vai pārdevējam. Saskaṇā ar Briseles regulu režīmiem, cel̦ot prasību pret profesionāli, patērētājs var izvēlēties dalībvalsts tiesu, kurā celt prasību, izvēloties vai nu sava domicila dalībvalsts tiesu, vai profesionāḷa domicila dalībvalsts tiesu. Vis-a-vis profesionālis šādu labvēlīgu jurisdikcijas noteikumu režīmu nebauda. Profesionāls pārdevējs vai pakalpojuma sniedzējs prasību pret patērētāju var celt tikai patērēja domicila dalībvalsts tiesā.

Briseles I regulas pārstrādātās versijas 17.-19. pants ir piemērojams tikai patērētāju līgumiem. Patērētāja līgums tiek definēts kā "līgums, ko noslēgusi persona, patērētājs, ar mērḳi, kas var būt uzskatāms par nesaistītu ar viṇas arodu vai profesiju”. Savukārt, ja līgumslēdzējas puses noslēdz līgumu mērḳim, kas saistīts ar to profesionālo darbību, ir uzskatāms, ka šìs personas atrodas ar otru līgumslēdzēju pusi līdzvērtīgā pozīcijā, un līdz ar to šajos apstākḷos Briseles Ibis regulā paredzētā īpašā aizsardzība attiecībā uz patērētājiem nav pamatota.

Līguma mērḳis un raksturs tā noslēgšanas brīdī ir galvenais, lai noteiktu, vai tas ir patērētāja līgums, nevis līgumslēdzējas puses subjektīvā situācija. Citiem vārdiem, ja līgums noslēgts tirdzniecības nolūkā, līgumslēdzēja puse nevar gūt labumu îpašo jurisdikcijas noteikumu piemērošanā, pat ja šī tirdzniecība vēl nav uzsākta vai nekad faktiski nav sākta, proti, šai līgumslēdzējai pusei nepiemìt patērētāja spējas Briseles Ibis regulas 17. panta darbības ietvarā. EST spriedumā lietā "Francesco Benincasa pret Dentalkit Srl." ir atzīmējusi: lai noteiktu, vai personai ir patērētāja spējas, jāatsaucas uz attiecīgās personas lomu konkrētajā līgumā, ṇemot vērā šì līguma mērḳi un dabu, nevis attiecīgās personas subjektīvo situāciju. Līdz ar to noteikumi, kas paredzēti, lai aizsargātu patērētāju kā pusi, kuru uzskata par ekonomiski vājāko pusi, attiecas tikai uz līgumiem, kas noslēgti, lai apmierinātu tā privātās patēriṇa vajadzības. İpaša aizsardzība, ko cenšas nodrošināt šie noteikumi, ir nepamatota attiecībā uz līgumiem tirdzniecības vai profesionālās darbības nolūkā, pat ja šì darbība ir tikai plānota nākotnē, jo tas, ka darbībai ir nākotnes raksturs, nekādā veidā nav atkāpe no tās tirdzniecības vai profesionālā rakstura. ${ }^{10}$

${ }^{7}$ OV, 20.12.2012., L 351, 1./32. lpp. (BG, ES, CS, DA, DE, ET, EL, EN, FR, GA, IT, LV, LT, HU, MT, NL, PL, PT, RO, SK, SL, FI, SV). İpašais izdevums horvātu valodā: 19. nodaḷa, 011. sējums, 289.-320. lpp.

${ }^{8}$ Regulu piemēro visām Eiropas Savienības dalībvalstīm, tostarp Dānijai, kura ir noslēgusi 2005. gada nolīgumu starp Eiropas Kopienu un Dānijas Karalisti par jurisdikciju un spriedumu atzīšanu un izpildi civillietās un komerclietās. Vajadzīgie tiesību aktu grozījumi Dānijā ir stājušies spēkā jau 2013. gada 1. jūnijā. Pieejams: https://e-justice.europa.eu/content_brussels_i_regulation_recast-350-lv.do.

${ }^{9}$ Padomes 22.12.2000. Regula Nr. 44/2001 (EK) par jurisdikciju un spriedumu atzī̌anu un izpildi civillietās un komerclietās. Publicēta OV 2004. gada īpašā izdevuma 19. nodaḷas 4. sējuma 42.-64. lpp.

10 Eiropas Savienības Tiesas 03.07.1997. spriedums lietā C-269/95 Francesco Benincasa v. Dentalkit Srl. [1997] ECR I-3767 I-3795, 15.-17. punkts. 
Jāatzīmē, ka Briseles Ibis regulas 17. pants attiecas uz trim patērētāju līgumu veidiem:

1) tas ir līgums par preču iegādi ar nomaksu pa daḷām;

2) tas ir līgums par aizdevumu, kas atmaksājams pa daḷām, vai par jebkāda cita veida kredìtu, kas izsniegts, lai finansētu preču iegādi;

3) visos citos gadījumos - līgums ir noslēgts ar personu, kas veic komercdarbību vai profesionālo darbību patērētāja domicila dalībvalstī vai jebkādā citā veidā vērš šādas darbỉbas uz minēto dalībvalsti vai vairākām dalībvalstīm, tostarp uz minēto dalíbvalsti, un līgums ietilpst šādu darbỉbu jomā.

Autores ieskatā īpaši savā bùtībā ar sarežgìitu juridisko konstrukciju ir Briseles Ibis regulas 17. punkta 1. punkta c) apakšpunkts, jo tas ir piemērojams visos citos gadījumos, bet pie īpašiem un konkrētiem apstākḷiem, kas norādīti šajā apakšpunktā. Redakcionāli nepastāv atškirība no Briseles I regulas noteikumiem, un ir saprotams, ka "visi citi gadījumi" arī aptver preču pārdošanas un pakalpojumu sniegšanas līgumus un, protams, līgumus, kas tagad tiek lielākoties slēgti interneta vidē. Viss, kas nepieciešams, ir tas, ka pirms līguma noslēgšanas bijusi kāda veida piesaiste vai uzaicinājums, kas vērsts attiecībā uz patērētāju. Šim uzaicinājumam jābūt saistītam tikai un vienīgi ar uzṇēmēja darbību un nav jābūt atkarīgam no tā, ko patērētājs varētu savā domicila dalībvalstī darīt, lai noslēgtu šo līgumu.

Briseles regulu režìmu interpretācijas vēsturē EST daudz darba ir veltījusi, strādājot ar diviem būtiskiem [tagad Briseles Ibis regulas 17. panta 1. punkta c) apakšpunkta] piemērošanas kritērijiem: kritērija [1] "vērst darbību" un [2] "distances līgums patērētāju strīdos" izpratni.

[1] "Vērst darbību".

Ne vienmēr ir viegli noteikt, vai profesionālis savu komercdarbību novirza uz patēētāja domicila valsti, lai līgumu varētu uzskatìt par "patērētāju līgumu" 17. panta 1. punkta c) apakšpunkta izpratnē. Ja pakalpojumi un preces tiek piedāvāti internetā, var izrādīties īpaši grūti noteikt, vai uzṇēmējdarbība ir vērsta uz patērētāja domicila dalībvalsti, jo informācijai par pakalpojumu vai preci var piekḷūt no jebkuras vietas pasaulē. Dalībvalstu tiesas ir vairākkārt iesniegušas EST interpretācijas jautājumus, un šajā jautājumā ir izstrādāta būtiska EST prakse. EST judikatūra stingri atbalsta ideju aizsargāt regulā iekḷauto vājāko pušu procesuālo stāvokli. ${ }^{11}$

Iespēja piekḷūt tīmekḷa vietnei pati par sevi nav pietiekama, lai secinātu, ka uzṇēmējs, kura darbība ir uzrādìta tā tīmekḷa vietnē, var uzskatìt to par savu darbību "vēršanu" patērētāja domicila dalībvalstī. Piemēram, piekḷūstot tādai interneta tīmekḷa vietnei kā https://www.mobile.de/, persona automātiski nekḷūst par patērētāju Briseles Ibis regulas izpratnē. Drīzāk ir jāpārliecinās, ka no "tīmekḷa vietnes un profesionāla vispārējās darbības izriet, ka tirgotājs paredzēja veikt uzṇēmējdarbību ar patērētājiem, kuru domicils ir vienā vai vairākās dalībvalstīs, tādā nozīmē, ka tas bija domājis noslēgt līgumu ar viṇiem". ${ }^{12}$

Attiecībā uz "vērst darbības" izpratni EST judikatūrā ir sniegts neizsmeḷošs to norāžu saraksts, kas noteic uzṇēmèja komerciālos nodomus un tādējādi to, vai

${ }^{11}$ Lazić V. Procedural Justice for 'Weaker Parties' in Cross-Border Litigation under the EU Regulatory Scheme. Utrecht Law Review, 2014, Vol. 10 (4), p. 106.

${ }^{12}$ EST 07.12.2010. spriedums apvienotajās lietās C-585/08 un C-144/09 Peter Pammer v. Reederei Karl Schlüter GmbH \& Co. KG (C-585/08) un Hotel Alpenhof GesmbH v. Oliver Heller (C-144/09), 71.-72., 74., 89. punkts. Pieejams: https://eur-lex.europa.eu/legal-content/LV/TXT/?uri=CELEX\%3A62008CJ0585 [aplūkots 15.03.2019.]. 
līgums ir iekḷauts Briseles Ibis regulas 17. panta 1. punkta c) apakšpunkta darbïbas jomā. "Acīmredzamas norādes", kas pierāda, ka komersants bija paredzējis tirgoties ar patērētājiem, ir:

- jebkura acīmredzama gribas izpausme noslēgt sliekšņa darījumus ar šīs dalībvalsts patērētājiem;

- norāde, pēc kuras komersants piedāvā savus pakalpojumus vai savas preces vienā vai vairākās dalībvalstīs, kas ir konkrēti nosauktas. Tas pats attiecas uz izdevumiem par atsauces pakalpojumu internetā, ko nodrošina meklētājprogrammas operators, lai patērētājiem, kuru domicils ir dažādās dalībvalstīs, atvieglotu piekl̦uvi komersanta tīmekḷa vietnei, kas arī pierāda šādas gribas esamību.

Ir arī citas norādes, kas var būt kombinētas savā starpā, kas nav izsmeḷošas un ko pārbauda valsts tiesa:

- darbības starptautiskais raksturs, piemēram, atsevišķām ar tūrismu saistītām darbībām;

- norāde, pa kādiem maršrutiem no citām dalībvalstīm var ierasties vietā, kur komersants ir dibināts;

- tas, ka ir izmantota valoda vai valūta, kas nav tā valoda vai valūta, ko parasti izmanto dalībvalstī, kurā ir dibināts komersants, pastāvot iespējai rezervēt un apstiprināt rezervāciju šajā citā valodā;

- norāde uz tālruṇa numuru kopā ar starptautisko kodu;

- izdevumi par atsauces pakalpojumu internetā, lai patērētājiem, kuru domicils ir citās dalībvalstīs, atvieglotu piekḷuvi komersanta vai tā starpnieka tìmekḷa vietnei;

- tas, ka ir izmantots pirmā līmena domēna nosaukums, kas nav tās dalībvalsts domēna nosaukums, kurā ir dibināts komersants, piemēram, “.de”, vai arì ir izmantoti tādi neitrāli pirmā līmeṇa domēna nosaukumi kā ".com” vai ".eu”;

- norāde uz starptautisko klientūru, ko veido klienti, kuru domicils ir dažādās dalībvalstīs, īpaši publicējot šādu klientu atsauksmes. ${ }^{13}$

Acīmredzot šāds plašs būtisko norāžu saraksts, kas var tikt ņemts vērā, nosakot faktu, ka komerciālā darbība ir vērsta uz patēētāja domicila dalībvalsti, dod priekšroku patērētāja pozīcijai, interpretējot 17. panta 1. punkta c) apakšpunktu.

[2] "Distances lïgums patērētāju strīdos".

Attiecībā uz "distances līguma” izpratni jāatzīmē, ka Briseles I regulas teksts, kas saglabāts arī Briseles Ibis regulā, atšķiras no Briseles konvencijas ${ }^{14}$ teksta. Ir izzudis (Briseles konvencijas) bijušajā 13. pantā esošais nosacījums, ka patērētājam savā valstī ir jāveic visas līguma noslēgšanai nepieciešamās darbības. Tas nozīmē, ka Briseles Ibis regulas 17. panta 1. punkta c) apakšpunkts ir piemērojams arī līgumiem, kas noslēgti dalībvalstī, kura nav patērētāja domicila dalībvalsts. Piemērošanas nosacījumi, kuriem patērētāju līgumiem ir jāatbilst, tagad, ņemot vērā jaunos sakaru līdzekḷus un elektroniskās tirdzniecības attīstību un lai nodrošinātu labāku patērētāju aizsardzību, ir formulēti daudz vispārīgāk nekā iepriekš, un

${ }^{13}$ EST 07.12.2010. spriedums lietā C-585/08 Peter Pammer pret Reederei Karl Schlüter GmbH \& Co KG un C-144/09 Hotel Alpenhof GesmbH pret Oliver Heller. Pieejams: https://eur-lex.europa.eu/Lex UriServ/LexUriServ.do?uri=CELEX:62008CJ0585:LV:HTML [aplūkots 16.03.2019.].

${ }^{14}$ Briseles konvencija par piekritību un spriedumu atzīšanu un izpildi civillietās un komerclietās. Pieejams: http://eur-lex.europa.eu/legal-content/EN/TXT/?uri=CELEX:41968A0927(01) [aplūkots 15.03.2019.]. 
netiek prasìts, lai līgums starp patērētāju un uzņēmēju būtu noslēgts kā distances līgums. Tātad līgums var būt noslēgts uz vietas, nevis attālināti, piemēram, pēc attiecīgās interneta tīmekḷa vietnes apmeklējuma, patērētājam klātienē apskatot preci uzṇēmèja domicila valstī.

Kaut arī saskaņā ar Briseles Ibis regulas 17. panta 1. punkta c) apakšpunktu līgumam nav obligāti jābūt noslēgtam no attāluma, logiski izriet, ka internetā noslēgtie līgumi, visticamāk, ietvers pārrobežu elementu, kas vajadzīgs, lai uzsāktu Briseles Ibis regulas piemērošanu.

\section{Briseles Ibis regulas uzlabojumi un trūkumi pārrobežu patērētāju strīdiem}

Būtiski uzsvērt, ka Briseles I regulas pārstrādātajā redakcijā ir ietvertas ievērojamas patērētājiem draudzīgas izmaiṇas.

Briseles I regulas pārstrādātajā redakcijā patērētājam tiek noteikta iespēja iesūdzēt profesionāli sava domicila dalībvalsts tiesā neatkarīgi no atbildētāja domicila, un tas nozīmē, ka patērētājs var atgriezties pie visām garantijām, ko ES sniedz patērētājiem materiālo tiesību sistēmā. ${ }^{15}$ Saskaṇā ar Briseles I regulu patērētājs varēja celt prasību tās dalībvalsts tiesā, kurā atradās viṇa domicils, ja profesionālis ir vai nu pastāvīgā dzīvesvieta, vai arī tas ir reǵistrēts Eiropas Savienībā. Ja uzñēmējam nebija domicils ES vai arī tā filiāle, ağentūra vai cita struktūrvienība neatradās ES teritorijā, piemērojami bija valsts starptautisko privāttiesību noteikumi. Saskaṇā ar Briseles I regulas pārstrādāto versiju patērētājs var celt prasību pret profesionāli tās dalībvalsts tiesās, kurā ir patērētāja domicils, neatkarīgi no otras puses domicila. Pie noteiktiem apstākliem faktiski tas nozīmē, ka patērētājs, kura domicils ir kādā no Eiropas Savienības dalībvalstīm un kurš pērk produktu, piemēram, izmantojot ASV vai K̦inas tīmekḷa vietni, piemēram, https://www.ebay.com/ vai $w w w . a l i e x p r e s s . c o m /$, var iesniegt prasību sava domicila dalībvalsts tiesā, kas būs kompetenta izskatìt strīdu.

Taču autores ieskatā tomēr pārrobežu patērētāju strīdos procesuālā piemērošanas shēma vēl joprojām nav ideāla. Pats sarežǵītākais, kas pašam patērētājam un tiesām rada un arī turpmāk radīs grūtības, ir Briseles Ibis regulas 17. panta 1. punkta c) apakšpunkta piemērošanas robežas, it ipaši pārrobežu e-komercdarijumos. Attīstoties mūsdienu tehnologijām un iespējām, ko piedāvā digitālā vide, ne vienmēr būs skaidrs, vai uzṇēmējs savu komerciālo darbību virzīs uz patērētāja domicila dalībvalsti, lai līgumu varētu uzskatīt par patērētāju līgumu regulas izpratnē. Jā, EST ir izvirzījusi veselu kritēriju sarakstu, kas jāṇem vērā, nosakot, vai komersants ir vērsis darbības patērētāja domicila valstī, taču tas situāciju nevienkāršo attiecībā uz e-komercdarījumu vides dažādo dabu.

Pārrobežu patērētāju strīdos piemērošanas sistēmas noslēgumā ir būtiski, ka tad, ja vienreiz spriedums ir pieṇemts, to var viegli izpildìt citās dalībvalstīs, ko attiecīgi Briseles Ibis regula nodrošina. Viennozīmīgi būtiskākais sarežğījums patērētājam būs profesionāḷa ienākumu vai īpašumu atrašanās vietas noskaidrošana. Briseles I regulas pārstrādātā versija neparedz centrālo iestāžu izveidošanas

\footnotetext{
15 Panopoulos G. The influence of the E-Commerce Directive on conflict of law and jurisdiction rules regarding the protection of tort victims and consumers. Collection Papers Fac. L. Nis, 2015, Vol. 70, p. 823.
} 
un sadarbības tīkla izveidi, lai atvieglotu patērētāja iespējas sprieduma izpildes stadijā pārrobežu lietā, kā tas, piemēram, ir paredzēts pārrobežu goimenes tiesībās. ${ }^{16}$ Patērētājam pašam jāvelta gan savs laiks, gan arī finanšu līdzekḷi, apzinot profesionāḷa ienākumus vai īpašumus, lai panāktu savā domicila dalībvalsts tiesā pieņemtā sprieduma izpildi citā ES dalībvalstī, kas var būt gan laikietilpīgi, dārgi vai citreiz pat neiespējami.

Pēdējais 45. pants Briseles I regulas pārstrādātajā redakcijā, kas attiecas uz spriedumu atzī̌sanu un izpildi, l̦auj profesionālajam pārdevējam vai pakalpojumu sniedzējam apstrīēet sprieduma izpildi, pamatojoties, piemēram, uz nesaderību ar sabiedrisko kārtību, kas noved pie vēl viena procesa, kurš bieži vien ir laikietilpīgs un dārgs. Tādēḷ dažos gadījumos, ja strīds ir par nelielām summām, pareizi izmantojot un piemērojot Eiropas rīkojumu neapstrīdētiem prasījumiem, Eiropas maksājuma rīkojumu vai procedūru maza apmēra prasībām, ${ }^{17}$ patērētājam tas varētu būt izdevīgāk un interesantāk.

\section{Kopsavilkums}

1. Viens no Eiropas Savienības mērķiem ir iekšējā patēriņa tirgus izveide - tā ir joma, kurā tiek nodrošināta brīva preču un pakalpojumu aprite, kas iekḷauj sevī arī pārrobežu darījumus ar patērētājiem. Arvien vairāk šie darījumi notiek ar interneta starpniecību. Iepirkšanās internetā atvieglo patērētājiem iespēju salīdzināt cenas, tādējādi ietaupot līdzekḷus, kas savukārt labvēlīgi ietekmē konkurenci.

2. Patērētājs pārrobežu darījumos nenoliedzami ir vājākā puse, jo īpaši, ja tas skar e-komerciju, jo vairumā gadījumu šai personai ir jāmaksā pirms piegādes. Tā rezultātā, ja rodas problēmsituācija ar līguma izpildi, pirmajam būs jārīkojas drīzāk patērētājam, nevis pārdevējam vai pakalpojumu sniedzējam.

3. Jāatzìmē, ka plaša EST judikatūra pārrobežu patērētāju strīdos norāda, ka jautājumus, kas skar starptautisko civilprocesu, neatkarīgi no ES likumdevēja centieniem tos padarīt skaidrākus, ne vienmēr ir iespējams pietiekami vispusīgi atrisināt.

4. Tomēr autores ieskatā, ja pārrobežu patērētāju strīdiem piedāvātie risinājumi no starptautiskā civilprocesa viedokḷa puses nebūs vienkārši un salīdzinoši lēti, patērētāji var vilcināties iesaistīties pārrobežu un e-komercijas darījumos, tādējādi apdraudot iekšèjā tirgus darbības funkcionēšanu ES.

16 Piemēram, Padomes 27.11.2003. Regula (EK) Nr. 2201/2003 par jurisdikciju un spriedumu atzǐšanu un izpildi laulības lietās un lietās par vecāku atbildību un par Regulas (EK) Nr. 1347/2000 atcelšanu. Publicēta OV 2004. gada īpašā izdevuma 19. nodaḷas 6. sējumā, 243.-271. lpp.

17 Eiropas Parlamenta un Padomes 11.07.2007. Regula Nr. 861/2007 (EK), ar ko izveido Eiropas procedūru maza apmēra prasībām. Publicēta OV 2007. gada 31. jūlijā, L 199, 1.-22. lpp.; Eiropas Parlamenta un Padomes 12.12.2006. Regula Nr. 1896/2006 (EK), ar ko izveido Eiropas maksājuma rīkojuma procedūru. Publicēta OV 2006. gada 30. decembrī, L 399, 1.-32. lpp.; Eiropas Parlamenta un Padomes 21.04.2004. Regula Nr. 805/2004 (EK), ar ko izveido Eiropas izpildes rīkojumu neapstrīdētiem prasījumiem. Publicēta OV 2004. gada īpašā izdevuma 19. nodaḷas 7. sējuma 38.-62. lpp. 